\title{
TELAAH INSENTIF PAJAK PENERBITAN BUKU ${ }^{1}$
}

\author{
Maxensius Tri Sambodo \\ Ahmad Helmy Fuady \\ Muhammad Soekarni \\ Nika Pranata \\ Mahmud Thoha \\ Darwin Syamsul Bahri \\ Sairi Erfanie \\ Firmansyah \\ Ernany Dwi Astuty \\ Saiful Hakam \\ Syarif Hidayat \\ Ari Juliano Gema \\ Sabartua Tampubolon \\ Linda Suryani \\ Pusat Penelitian Ekonomi, Lembaga Ilmu Pengetahuan Indonesia (PPE-LIPI)
}

\begin{abstract}
The creative economy is expected to be increasingly able to improve the quality of national economic development. The publishing sector which is one of 16 (sixteen) creative industry fields is expected to play a more important role to educate people. Thus, it is necessary to develop supporting publishing industry in Indonesia. This article is intended to answer the following five issues: (i) how are the developments, obstacles, opportunities and challenges in the publishing activities? (ii) what is the value chain of publishing business, and how is the tax policy in each chain? (iii) how should tax book publishing incentives be provided? (iv) what is the impact of providing tax incentives on the prospects of a publishing business? ( $v$ ) how can the provision of tax incentives encourage the development of the publishing sector and the competitiveness of its industry? This study uses a mixed method approach and information deepening is carried out in 7 provinces in Indonesia. This article has resulted two special findings: (i) identifying crucial issues in the book publishing industry; and (ii) produce a formulation of government policy recommendations, specifically to provide tax incentives to encourage the growth of the publishing sector.
\end{abstract}

Keywords: creative economy; publishing book; tax incetives

\section{ABSTRAK}

Ekonomi kreatif diharapkan semakin mampu meningkatkan kualitas pembangunan ekonomi nasional. Bidang penerbitan yang merupakan satu dari 16 (enam belas) bidang industri kreatif diharapkan dapat berperan semakin nyata untuk mencerdaskan kehidupan bangsa. Dengan demikian, perlu dilakukan langkah-langkah perbaikan untuk meningkatkan ekosistem industri penerbitan. Salah satu kebijakan yang mendapat perhatian besar yaitu rencana pemberian insentif penerbitan buku. Untuk mengkaji kebijakan tersebut, maka artikel ini dimaksudkan menjawab lima permasalahan berikut, yaitu: (i) bagaimana perkembangan, hambatan, peluang dan tantangan bidang penerbitan? (ii) seperti apa mata rantai usaha penerbitan berjalan selama ini dan bagaimana kebijakan perpajakan dalam masing-masing mata rantai? (iii) bagaimana insentif pajak penerbitan buku sebaiknya diberikan? (iv) bagaimana dampak pemberian insentif

\footnotetext{
${ }^{1}$ Istilah penerbitan merujuk pada konsep yang diemban oleh Badan Ekonomi Kreatif. Penerbitan adalah suatu usaha atau kegiatan mengelola informasi dan daya imajinasi untuk membuat konten kreatif yang memiliki keunikan tertentu, dituangkan dalam bentuk tulisan, gambar dan/atau audio ataupun kombinasinya, diproduksi untuk dikonsumsi publik, melalui media cetak, media digital, ataupun media daring, untuk mendapatkan nilai ekonomi, sosial, ataupun seni dan budaya yang lebih tinggi (Rencana Pengembangan Penerbitan Nasional 2015-2019).

2Email: smaxensius@yahoo.com
} 


\section{2 | Bina Ekonomi}

pajak terhadap prospek usaha penerbitan? (v) bagaimana agar pemberian insentif pajak dapat mendorong perkembangan bidang penerbitan dan daya saing industrinya? Studi ini menggunakan pendekatan mixed method dan pendalaman informasi dilakukan di tujuh (7) provinsi di Indonesia. Penelitian ini menghasilkan temuan berikut: (i) mengidentifikasikan pokok-pokok permasalahan yang krusial dalam industri penerbitan buku; dan (ii) menghasilkan rumusan rekomendasi kebijakan pemerintah, khususnya untuk memberikan insentif pajak untuk mendorong pertumbuhan bidang penerbitan dalam hal ini buku.

Kata kunci: ekonomi kreatif; bidang penerbitan; insentif pajak penerbitan

\section{PENDAHULUAN}

Untuk mendorong peran ekonomi kreatif yang semakin tinggi bagi pembangunan ekonomi nasional, maka pemerintah perlu merancang kebijakan berbasis pada pendekatan ekosistem. Pendekatan ini menekankan, kebijakan yang berbasis pada optimasi kepentingan sektoral, namun abai atau bahkan 'mengorbankan' kepentingan sektor lainnya, penting untuk dihindari. Kebijakan yang baik bukan dirancang dalam strategi 'zero sum game', namun harus mampu menciptakan 'pareto improvement' bagi semua agen pembangunan (Stiglitz, 1998; Nicholson \& Snyder, 2009).

Badan Ekonomi Kreatif, memiliki tugas berat untuk memastikan, 16 bidang yang menjadi arena kerjanya tumbuh dalam suatu ekosistem yang 'bersahabat'. Dengan demikian, peranan ekonomi kreatif dalam hal pembentukan Produk Domestik Bruto (PDB), penciptaan kesempatan kerja, dan sebagai pendorong ekspor, semakin meningkat ${ }^{3}$.

Protes keras yang dilakukan oleh novelis best seller seperti Tere Liye (Kompas, September 8, 2017) dan Dewi "Dee" Lestari (Kontan, September 8, 2017) terhadap pajak yang tinggi bagi penulis, telah mendapat perhatian besar dari pemerintah (Kompas, September 11, 2017). Pajak yang seharusnya menjalankan fungsi mengatur (regulerend) ternyata telah menjadi disinsentif bagi penulis. Hal ini akan mengganggu potensi pertumbuhan kreativitas bidang penerbitan buku di masa depan. Sementara itu, prinsip-prinsip umum pemungutan pajak harus memenuhi kaidah keadilan, berdasarkan pada undang-undang, tidak mengganggu perekonomian, efisiensi, dan prisip kesederhanaan (Mardiasmo, 2009).

Kegaduhan perpajakan tentu merupakan salah satu manifestasi dari kompleksitas pemasalahan dunia pernerbitan nasional atau pada sisi lain, ada hal yang 'kurang pas' dengan prinsip-prinsip perpajakan itu sendiri. Untuk mengungkap permasalahan yang dihadapi oleh para penulis, tentu diperlukan studi mendalam untuk melakukan pemetaan permasalahan yang ada. Walaupun sasaran akhir studi ini lebih pada merumuskan insentif pajak, bukan berarti faktor lainnya selain pajak tidak penting. Dengan kata lain, aspek perpajakan menjadi pintu masuk untuk melakukan konstruksi permasalahan di bidang penerbitan buku.

Dengan mengambil pendekatan ini, maka rumusan kebijakan dapat disarankan secara komprehensif, tepat dan inklusif. Hal ini berarti, kebijakan insentif pajak buku mampu mengayomi kepentingan semua pelaku di bidang penerbitan buku. Tujuan akhir dari studi ini adalah untuk menciptakan bidang penerbitan buku yang profesional dan akuntabel serta meningkatnya literasi masyarakat.

\footnotetext{
${ }^{3}$ Aplikasi dan game developer; arsitektur; desain interior; desain komunikasi visual; desain produk; fashion; film; animasi dan video; fotografi; kriya; kuliner; musik; penerbitan; periklanan; seni pertunjukan, seni rupa, dan televisi dan radio.
} 
Sistematika tulisan ini terbagi dalam delapan bagian, setelah pendahuluan dan metode penelitian, diberikan analisis terkait dengan kondisi makro perbukuan di Indonesia dan perbandingan dengan negara. Bagian empat berisi bahasan tentang kondisi terkini bidang penerbitan dilihat dari sisi hambatan, peluang dan tantangan. Bagian kelima, berisi analisis akan kebijakan pajak penerbitan dan dilanjutkan dengan pertimbangan perlunya memberikan insentif pajak penerbitan. Bagian keenam membangun dasar perlunya pemberian insentif buku dan dilanjutkan dengan usulan-usulan insentif pajak penerbitan yang bisa dipilih oleh pemerintah, dan bagian terakhir ditutup dengan kesimpulan.

\section{METODE PENELITIAN DAN DATA}

Studi ini dilakukan dengan pendekatan mixed method atau penelitian gabungan (kuantitatif dan kualitatif). Metode kuantitatif dilakukan untuk menemukan skenario pemberikan insentif serta melakukan proksi-proksi dampak terhadap penerimaan negara baik dalam jangka pendek, menengah dan panjang. Metode kualitatif dilakukan untuk menggali pandangan para pelaku usaha di industri penerbitan akan ekosistem yang saat ini berjalan, serta ekspektasi akan ekonomi ideal. Evaluasi best practices di Malaysia dilakukan untuk memperkaya analisis kualitatif dan kuantitatif.

Penelitian ini memetakan mata rantai kepentingan mulai dari bidang kreasi (penulis), produksi, distributor, dan pengguna akhir. Demikian pula, dengan pertimbangan perbedaan karakteristik antara jenis buku (akademis dan non akademis); media (elektronik dan cetak); serta aktor (penerbit anggota IKAPI dan non-IKAPI), maka dalam proses pengumpulan data dimensi-dimensi tersebut dicermati dengan lebih baik. Sementara itu, diperhatikan juga pelaku usaha penerbitan baik dalam kategori skala usaha Usaha Kecil dan Menengah (UKM) dan Usaha Besar (UB).

Studi ini menganalisis data primer dan sekunder. Data primer dikumpulkan dari hasil wawancara mendalam bersama para pelaku usaha dan melalui diskusi kelompok terarah (Focus Group Discussion) bersama pihak-pihak yang kompeten. Data sekunder akan dikumpulkan dari Kementerian Keuangan, Badan Pusat Statistik, Lembaga Penerbitan, dan sumber data sekunder lainnya yang bisa diandalkan. Teknik analisis kuantitatif dilakukan dengan membuat skenario perpajakan bagi penulis dan juga skenario atas pemberlakuan pajak pertambahan nilai (PPN). Selanjutnya data dianalisis dengan teknik triangulasi yaitu dengan menyinkronkan antara konsep, wawacara ataupun diskusi, dan data sekunder. Visitasi untuk melakukan wawancara mendalam dan diskusi bersama pelaku usaha di industri penerbitan, pemerintah pusat dan daerah akan dilakukan di 7 provinsi yaitu: DKI Jakarta, DI Yogyakarta, Sulawesi Selatan, Jawa Timur, Riau, Kalimantan Barat, dan Jawa Barat.

\section{KONDISI MAKRO PERBUKUAN DI INDONESIA}

Kondisi makro perbukuan di Indonesia ditinjau dari aspek kontribusi terhadap perekonomian, sebaran industri, produksi buku, penjualan buku, kondisi literasi, dan komparasi kebijakan royalti dengan pajak pertambahan nilai. Jika dilihat dari kontribusinya pada perekonomian Indonesia dapat dikatakan bahwa bidang penerbitan menyumbang sekitar $6 \%$ dari total produksi bidang ekonomi kreatif atau bidang ini menjadi penyumbang produk bidang ekonomi kreatif lima terbesar setelah kuliner, fashion, kriya, serta televisi dan radio (BEKRAF \& 
BPS, 2017). Rata-rata nilai ekspor (FOB) industri penerbitan baru sekitar USD 22.335 (Rp302.000.000) atau 0,12\% dari nilai total ekspor ekonomi kreatif. Selanjutnya, industri penerbitan mampu menyerap tenaga kerja sebanyak 2,89\% (sekitar 460 ribu orang) dari total tenaga kerja ekonomi kreatif nasional.

Jika dilihat dari persebarannya, data IKAPI tahun 2015 menyebutkan, terdapat sebanyak 1.328 penerbit di Indonesia yang terdaftar di lembaga tersebut (IKAPI, 2015). Namun demikian, dari jumlah tersebut hanya sebanyak 53\% (709 penerbit) yang aktif atau secara rutin mampu menerbitkan buku minimal 10 judul buku per tahun. Kondisi sebaran penerbit sebagian besar berada di pulau Jawa atau sekitar $97 \%$ dari jumlah penerbit nasional yang aktif (lihat Tabel 1). Dari aspek skala usaha penerbitan di Indonesia, masih didominasi oleh penerbit berskala kecil.

Tabel 1. Sebaran Penerbit di Indonesia

\begin{tabular}{|c|c|c|c|c|c|c|}
\hline \multirow[t]{2}{*}{ Lokasi } & \multirow{2}{*}{$\begin{array}{l}\text { Jumlah } \\
\text { penerbit }\end{array}$} & \multicolumn{2}{|c|}{$\begin{array}{c}\text { Jumlah penerbit } \\
\text { berdasarkan } \\
\text { status }\end{array}$} & \multicolumn{2}{|c|}{$\begin{array}{c}\text { Persentase } \\
\text { keaktifan } \\
\text { penerbit }\end{array}$} & \multirow{2}{*}{$\begin{array}{c}\text { Persentase } \\
\text { penerbit aktif } \\
\text { berdasarkan } \\
\text { wilayah }\end{array}$} \\
\hline & & Aktif & $\begin{array}{l}\text { Tidak } \\
\text { Aktif }\end{array}$ & Aktif & $\begin{array}{l}\text { Tidak } \\
\text { Aktif }\end{array}$ & \\
\hline Jakarta & 505 & 293 & 212 & 58 & 42 & 41 \\
\hline Jawa Barat & 283 & 143 & 140 & 51 & 49 & 20 \\
\hline $\begin{array}{l}\text { Jawa Tengah, } \\
\text { Yogyakarta dan Jawa } \\
\text { Timur }\end{array}$ & 378 & 210 & 168 & 56 & 44 & 30 \\
\hline Luar Jawa & 160 & 63 & 97 & 39 & 61 & 9 \\
\hline Total & 1,328 & 709 & 617 & 53 & 46 & 100 \\
\hline
\end{tabular}

Sumber: IKAPI (2015)

Dari sisi produksi, jumlah buku yang dihasilkan di Indonesia masih rendah. Pada 2015, ada 45.161 judul buku baru. Secara kuantitas jumlah tersebut memang di atas beberapa negara Asia lainnya seperti, Malaysia (15.354 judul), Thailand (11.334 judul), dan Filipina ( 9.480 judul). Namun, jika dibagi dengan jumlah penduduk Indonesia di tahun yang sama, maka ada sekitar 174 judul buku per satu juta penduduk, sedangkan negara-negara lain untuk jumlah penduduk yang sama jumlah buku yang dihasilkan di atas angka tersebut, seperti Korea Selatan ( 909 judul buku), Jepang (603 judul buku), Malaysia (500 judul buku) (IPA, 2016). Indonesia lebih baik dibandingkan Thailand (168 judul buku), Filipina (93 judul buku), dan Afrika Selatan (63 judul buku) (lihat Gambar 1).

Dari segi penjualannya, sebagian besar penjualan buku di Indonesia dilakukan oleh toko buku (59\%), buku sekolah (35\%), dan sisanya adalah melalui proyek pengadaan buku (6\%) (BEKRAF \& BPS, 2017). Pada 2014, sebanyak 62,6 juta eksemplar/tiras/oplah terjual melalui toko buku. Capaian ini mengalami penurunan sekitar 10,2\% dari tingkat penjualan buku tahun sebelumnya sebanyak 69,7 juta eksemplar. Meskipun dari sisi kuantitas jumlah eksemplar yang terjual menurun, namun dari sisi nominal nilai penjualan meningkat. Pada 2013, nilai penjualan buku melalui toko buku mencapai sekitar Rp7,3 triliun, sedangkan pada 2014 nilainya mencapai Rp8,5 triliun. Artinya, terdapat kenaikan rata-rata harga per buku dari 2013 ke 2014 sebesar 29,7\%. Pada 2013 harga rata-rata per buku adalah Rp104.635 sedangkan pada 2014 harga ratarata per buku mencapai Rp135.661. Proporsi penjualan buku berdasarkan penyalurannya ditunjukkan oleh Gambar 2. 
Gambar 1. Rasio Jumlah Judul Buku Baru per Satu Juta Penduduk

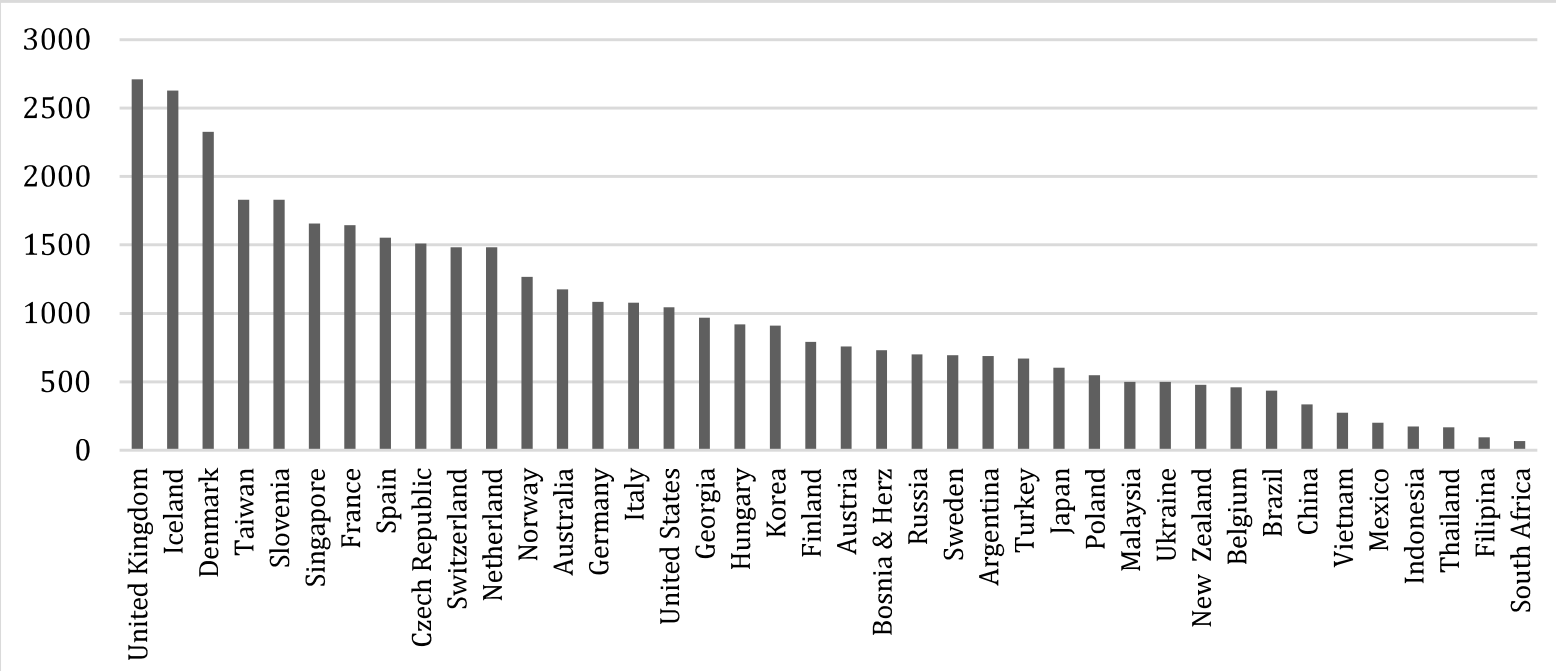

Sumber: IPA (2016a) dan MABOPA (2016)

\section{Gambar 2. Proporsi Penjualan Buku Berdasarkan Penyalurannya}

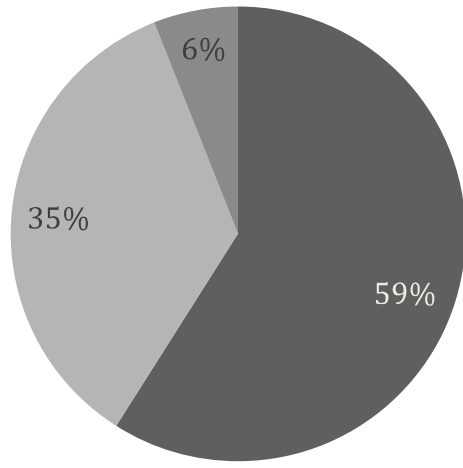

— Toko buku Buku sekolah @ Proyek pengadaan buku

Sumber: BEKRAF dan BPS (2017)

Sementara itu, dari sisi pembaca, saat ini, kondisi literasi di Indonesia sangat memprihatinkan dan bisa dibilang 'darurat literasi'. Berdasarkan survei yang dilakukan oleh UNESCO pada tahun 2011, indeks minat baca Indonesia berada di posisi yang sangat rendah yaitu 0,001 . Angka tersebut memiliki arti bahwa dari seribu penduduk hanya satu orang yang memiliki minat baca. Selain itu, survei yang bertajuk Progress in International Reading Literacy Study yang dilakukan oleh International Study Center, Lynch School of Education, Boston College (2011) dengan mengambil sampel siswa kelas 4-5 SD (usia sekitar 10 tahun) menempatkan Indonesia di peringkat 43 dari 48 negara yang disurvei terkait dengan kemampuan membaca (lihat Tabel 2). Hampir 2/3 dari siswa Indonesia yang dijadikan sebagai sampel termasuk ke dalam kategori kemampuan membaca yang rendah. Dengan kata lain, para siswa tersebut baru mampu mencari dan menemukan pernyataan eksplisit di dalam bacaan. Mereka belum mampu untuk memahami bacaan, mengidentifikasi fitur dan gaya bahasa (majas, perumpaman, dan lainlain), apalagi sampai bisa mengintegrasikan gagasan dan fakta pada sebuah bacaan serta mengintepretasikannya. 
Tabel 2. Kondisi Literasi Indonesia

\begin{tabular}{ccc}
\hline \multicolumn{2}{l}{ Negara dengan 10 Nilai Literasi Terbawah } & \\
\hline Peringkat & Negara & Nilai \\
\hline 39 & Iran & 457 \\
\hline 40 & Kolombia & 448 \\
\hline 41 & Uni Emirat Arab & 439 \\
\hline 42 & Arab Saudi & 430 \\
\hline $\mathbf{4 3}$ & Indonesia & $\mathbf{4 2 8}$ \\
\hline 44 & Qatar & 425 \\
\hline 45 & Kuwait & 419 \\
\hline 46 & Botswana & 419 \\
\hline 47 & Oman & 391 \\
\hline 48 & Maroko & 310 \\
\hline Nilai rata - rata 48 negara & & $\mathbf{5 0 5}$ \\
\hline
\end{tabular}

Sumber: TIMSS dan PIRLS International Study Center (2011)

Sejauh ini pemerintah Indonesia menerapkan tarif PPN buku cetak sebesar $10 \%$ dan pajak royalti penulis sebesar $15 \%$. Tarif ini termasuk besar, jika dibandingkan dengan negara negara lain. Tabel 3 memperlihatkan banyak negara sudah memberikan pajak PPN sebesar $0 \%$ untuk buku yang dicetak. Demikian juga dengan pajak royalti, banyak negara sudah menihilkan pajak royalti penulis. Salah satu negara yang tidak hanya menerapkan tarif PPN nol persen untuk buku cetak dan royalti penulis, tetapi bahkan memberikan banyak insentif lain, adalah Malaysia.

Tabel 3. Informasi Pajak Pertambahan Nilai dan Royalti Beberapa Negara di Asia

\begin{tabular}{lcccc}
\hline \multicolumn{1}{c}{ Negara } & $\begin{array}{c}\text { Tarif VAT/GST } \\
\text { Standar }\end{array}$ & $\begin{array}{c}\text { Tarif VAT/GST } \\
\text { Buku Cetak }\end{array}$ & $\begin{array}{c}\text { Tarif VAT/GST } \\
\text { E-Books }\end{array}$ & $\begin{array}{c}\text { Pajak } \\
\text { Royalti }\end{array}$ \\
\hline China & 17 & 13 & No info & 10 \\
Hong Kong & 0 & 0 & 0 & 0 \\
India & $5-15$ & 0 & 0 & 10 \\
Indonesia & $\mathbf{1 0}$ & $\mathbf{1 0}$ & $\mathbf{1 0}$ & $\mathbf{1 5}$ \\
Jepang & 8 & 8 & 8 & 0 \\
Malaysia & 6 & 0 & 6 & 0 \\
Mongolia & 10 & 10 & 10 & 10 \\
Filipina & 12 & 0 & 12 & 20 \\
Singapura & 7 & 7 & 7 & 10 \\
Korea Selatan & 10 & 0 & 0 & 0 \\
Taiwan & 5 & 5 & 5 & 10 \\
Thailand & 7 & 0 & 7 & 3 \\
Vietnam & 10 & 5 & 0 & 10 \\
\hline
\end{tabular}

Sumber: IPA (2016b) dan PwC (2017)

Tidak hanya menihilkan tarif PPN buku cetak, per 1 Januari 2018, pemerintah Malaysia juga akan memberikan tarif PPN 0\% pada komik, jurnal, majalah, dan terbitan berkala lainnya. Mereka juga memberikan kupon pembelian buku kepada para pelajar senilai 250 Ringgit Malaysia atau sekitar Rp831.000/tahun/siswa. Pemerintah negeri jiran itu juga memberi keringanan pajak (tax relief) berupa pengurangan kredit pajak kepada masyarakat yang membeli buku, jurnal, atau majalah senilai jumlah pembeliannya dengan maksimum pengurangan kredit pajak sebesar 2.500 Ringgit Malaysia atau setara dengan Rp8,3 juta. 


\section{HAMBATAN, PELUANG DAN TANTANGAN BIDANG PENERBITAN}

Proses penerbitan buku mulai dari penulisan hingga terbacanya buku oleh pengguna akhir, merupakan suatu proses yang bersifat kolektif. Berawal dari naskah yang ditulis oleh penulis dan selanjutnya ditawarkan kepada penerbit untuk diproses lebih lanjut. Walaupun, penulis merupakan kreator dan sumber dari segala aktivitas perbukuan, bisa pula ide penerbitan berawal dari penerbit yang menangkap kebutuhan pasar tentang suatu situasi atau fenomena yang penting untuk ditulis. Ide tersebut kemudian ditawarkan oleh penerbit kepada penulis yang dinilai memiliki kompetensi untuk menuliskannya. Terlepas dari pihak mana yang lebih berperan antara penerbit dan penulis dalam proses penerbitan buku, substansi penulisan buku merupakan bentuk kontribusi penulis yang tidak dapat diabaikan. Substansi buku merupakan hasil kerja keras penulis dalam meramu berbagai ide yang dituangkan dalam rangkaian kata dan ilustrasi.

Secara umum pelaku bidang penerbitan buku terdiri atas penulis, penerbit, distributor, toko buku, dan pengguna akhir. Tabel 4 berisi ringkasan tentang hambatan, peluang, dan tantangan yang dihadapi oleh masing-masing pelaku di penerbitan, hasil penelitian.

Tabel 4. Pemetaan Hambatan, Peluang dan Tantangan untuk Masing-Masing Pelaku Perbukuan

\begin{tabular}{|c|c|c|}
\hline No. & Pelaku & Temuan Studi \\
\hline 1 & Penulis & $\begin{array}{l}\text { 1. Pendapatan dari profesi sebagai penulis pada umumnya belum dapat } \\
\text { diandalkan untuk memenuhi kebutuhan hidup penulis } \\
\text { 2. Pengakuan dan penghargaan atas eksistensi penulis oleh pemerintah } \\
\text { belum memadai } \\
\text { 3. Posisi penulis dalam rantai nilai penerbitan, berada dalam posisi tawar } \\
\text { yang paling lemah } \\
\text { 4. Pajak royalti dirasa terlalu tinggi baik bagi penulis yang sudah memiliki } \\
\text { nama, apalagi bagi penulis pemula } \\
\text { 5. Geliat kehadiran penulis-penulis muda berbakat mulai tumbuh di } \\
\text { banyak daerah, hal ini ditandai oleh semakin maraknya self publishing } \\
\text { yang ditemukan di banyak daerah }\end{array}$ \\
\hline 2 & Penerbit & $\begin{array}{l}\text { 1. Kenaikan biaya produksi, menyebabkan harga buku semakin mahal } \\
\text { 2. Banyak penerbit menjual bukunya baik dengan cara book printed dan } e \text { - } \\
\text { book, dan yang terakhir memperlihatkan perkembangan yang baik } \\
\text { 3. Secara teknis upaya memajukan usaha perbitan di luar Jawa terkendala } \\
\text { oleh: relatif rendahnya kualitas dan kapasitas SDM, lemahnya akses } \\
\text { teknologi yang lebih maju, rendahnya penguasaan manajemen } \\
\text { penerbitan, ketersediaan dan harga input yang relatif mahal, dan } \\
\text { tingginya biaya distribusi. } \\
\text { 4. Penerbit menyebutkan adanya indikasi jumlah buku yang dicetak, tiras } \\
\text { buku menunjukkan penurunan atau di bawah kondisi skala ekonomis } \\
\text { yang idealnya dapat dicapai. } \\
\text { 5. Kondisi saat ini semakin maraknya kehadiran penerbit-penerbit Indie } \\
\text { (independent). Mereka mencoba melakukan 'perlawanan' atas kondisi } \\
\text { perbukuan konvensional yang lebih berorientasi pada profit, dan } \\
\text { kurang memberikan ruang pada buku-buku yang memiliki idealisme'. } \\
\text { 6. Pembajakan buku masih sering terjadi dan merugikan banyak pihak } \\
\text { khususnya penulis, penerbit dan negara. } \\
\text { 7. Belum ada penegakkan hukum tindakan pembajakan buku. } \\
\text { 8. Penerbit yang mengandalkan pada pesanan buku dari pemerintah, telah } \\
\text { kehilangan pangsa pasarnya karena pemerintah telah merubah pola } \\
\text { pengadaan buku dalam bentuk pembelian naskah untuk selanjutnya } \\
\text { dicetak. }\end{array}$ \\
\hline
\end{tabular}




\begin{tabular}{|c|c|c|}
\hline No. & Pelaku & Temuan Studi \\
\hline 3 & Distributor & $\begin{array}{l}\text { 1. Distributor lepas membeli buku kepada penerbit dengan sistem jual- } \\
\text { beli putus, sedangkan kepada toko buku menggunakan sistem } \\
\text { konsinyasi. Dengan demikian, distributor sebenarnya menanggung } \\
\text { risiko yang cukup besar apabila buku tidak laku dan dikembalikan } \\
\text { (return) oleh toko buku. } \\
\text { 2. Distributor kerap kali menghadapi kendala ketidaklancaran } \\
\text { pembayaran dari toko buku. } \\
\text { 3. Porsi rabat/diskon yang diperoleh toko buku yang memiliki reputasi } \\
\text { dinilai terlau besar (misalkan untuk sistem konsinyasi, kredit, dan tunai } \\
\text { porsi rabat yang diminta masing-masing sebesar: } 35 \%, 40 \% \text {, dan } 45 \% \text { ). } \\
\text { Sedangkan rabat yang diperoleh distributor sekitar } 15 \% \text {. } \\
\text { 4. Keterbatasan infrastruktur seperti jalan, pelabuhan dan sarana } \\
\text { transportasi menyebabkan biaya ekspedisi/pengiriman buku ke luar } \\
\text { Jawa juga menjadi lebih mahal. }\end{array}$ \\
\hline 4 & Toko buku & $\begin{array}{l}\text { 1. Penjualan buku yang semakin menurun, bahkan banyak toko buku yang } \\
\text { sudah gulung tikar. Hal ini karena, untuk buku-buku sekolah sering } \\
\text { terjadi perubahan kurikulum, bahkan sebelum buku terjual habis, } \\
\text { mahasiswa mulai kurang tertarik membaca buku karena materi kuliah } \\
\text { dapat dengan mudah diunduh dari internet; dan relatif rendahnya } \\
\text { minat baca dan daya beli masyarakat. } \\
\text { 2. Toko-toko buku skala kecil yang berada di luar Jawa menghadapi } \\
\text { masalah: jaringan toko buku yang masih sangat terbatas; keterbatasan } \\
\text { sumber pengadaan buku; penerbit/ distributor lokal biasanya langsung } \\
\text { menjual buku terbitannya secara langsung ke sekolah-sekolah, dan } \\
\text { perpustakaan daerah; sistem pembelian buku kepada distributor } \\
\text { menggunakan sistem kredit untuk jangka waktu } 1-2 \text { bulan sehingga } \\
\text { harus menanggung risiko ketika buku tidak habis terjual. }\end{array}$ \\
\hline 5 & $\begin{array}{l}\text { Pengguna } \\
\text { akhir }\end{array}$ & $\begin{array}{l}\text { 1. Secara umum minat baca masyarakat masih relatif rendah akibat belum } \\
\text { berkembangnya budaya membaca masyarakat. } \\
\text { 2. Fasilitas umum untuk mengakses buku seperti perpustakaan dan } \\
\text { perpustakaan keliling sudah mulai berkembang, tetapi masih kurang } \\
\text { memadai dibandingkan dengan banyaknya masyarakat yang harus } \\
\text { dilayani, sehingga aksesnya masih harus ditingkatkan. } \\
\text { 3. Ketersediaan anggaran untuk pengadaan buku semakin berkurang, } \\
\text { kurangnya pustakawan/wati yang mengelola perpustakaan, kesulitan } \\
\text { mengklasifikasi buku pendidikan dan buku umum terkait perpajakan } \\
\text { ketika melakukan pengadaan buku baru. }\end{array}$ \\
\hline
\end{tabular}

Sumber: Data primer diolah

Menimbang pada banyak dan rumitnya permasalahan serta hambatan di bidang penerbitan buku, pemerintah telah membuat serangkaian kebijakan untuk semakin menggairahkan dunia penerbitan nasional. Peran pemerintah pusat dan daerah yang telah dijalankan dalam berbagai kebijakan. Pertama, pemerintah telah membentuk Badan Pertimbangan dan Pengembangan Buku Nasional (BPPBN) melalui Keppres No. 5 Tahun 1978. Kedua, pemerintah juga mendirikan Pusat Perbukuan (Pusbuk) dengan Keppres No. 4 Tahun 1987 di bawah Departemen Pendidikan dan Kebudayaan. Kongres Perbukuan I yang diinisiasi oleh Pusbuk merekomendasikan disusunnya UU Perbukuan. Langkah lain pemerintah Indonesia adalah membentuk Dewan Buku Nasional (DBN) melalui Keppres No. 110 Tahun 1999. Kelahiran DBN tidak terlepas dari kurang berperannya BPPBN dan dorongan Kongres Perbukuan Nasional yang dipelopori Pusat Perbukuan Depdikbud serta Musyawarah Nasional IKAPI. DBN juga lahir dari tuntutan reformasi Perbukuan Nasional. Dalam pemerintahan Presiden BJ Habibie, pemerintah mencabut Keppres tentang BPPBN. Namun pada tahun 2014 Presiden membubarkan DBN karena dianggap sebagai lembaga yang kurang efektif. Sayangnya, 
pemerintah membubarkan DBN tanpa memberikan solusi alternatif dan ini cenderung memperparah kondisi perbukuan nasional.

Ketika landasan hukum yang mengatur peran pemerintah dan pemerintah daerah selama ini dianggap masih belum jelas, pemerintah bersama lembaga legislatif melahirkan UU No. 3/2017 tentang Sistem Perbukuan, yang diharapkan bisa memberikan ruang untuk meningkatkan efektivitas peran pemerintah dalam perbukuan serta terbangunnya harmonisasi kebijakan dengan peraturan perundang-undangan terkait lainnya. Lebih jauh UU Perbukuan ini juga diharapkan mampu meningkatkan peran pemerintah daerah.

Di sisi lain, dukungan pemerintah daerah dalam penerbitan bermuatan lokal, terutama buku sastra, masih sangat minim. Misalkan, saat ini Dinas Kebudayaan Riau hanya mengumpulkan data dan naskah, dan bila ada yang ingin menerbitkan buku harus membayar. Kurang optimalnya peran pemerintah daerah, disebabkan juga oleh tugas dan fungsi dinas-dinas terkait di daerah yang belum saling sinergi. Misalkan, di Provinsi Daerah Istimewa Yogyakarta, Dinas Kebudayaan memiliki dana cukup besar yang bersumber dari Dana Keistimewaan Yogyakarta, tetapi efektivitasnya dalam mendukung perbukuan masih terbatas pada buku-buku kebudayaan yang diterbitkan dan dihadiahkan sebagai cindera mata bagi tamu-tamu Pemda. Sementara di Makassar dinas kebudayaan sama sekali tidak melakukan penerbitan buku karena tidak dalam tugas dan fungsinya sehingga tidak memperoleh anggaran.

\section{KEBIJAKAN PERPAJAKAN DALAM PENERBITAN BUKU}

Secara umum, banyak penulis di Indonesia, jauh lebih khawatir jika ia tidak membuat tulisan dibandingkan memikirkan tentang besaran royalti yang diterima, ataupun besaran pajak yang harus dibayarkan. Namun demikian, banyak penulis baru menyadari akan potensi pendapatan yang lebih baik dapat ia terima jika saja ia paham tentang urusan perpajakan, misalkan mulai dari pentingnya memiliki Nomor Pokok Wajib Pajak (NPWP), hingga restitusi pajak (Kompas, September 8, 2019). Ada dua jenis perpajakan yang berdampak langsung terhadap ekosistem perbukuan di Indonesia yaitu: (i) pajak penghasilan; dan (ii) pajak pertambahan nilai. Berikut disampaikan analisis praktik kedua perpajakan tersebut di dunia penerbitan.

Berkaitan dengan pajak penghasilan, dalam UU No. 3 Tahun 2017 tentang Sistem Perbukuan, Pasal 13 butir e dikatakan "penulis berhak mendapatkan imbalan atas hak penerbitan naskah tulisannya". Selanjutnya dalam penjelasan UU tersebut dikatakan bahwa imbalan antara lain dalam bentuk royalti, honorarium, dan upah. Tingkat keberhasilan seorang penulis buku biasanya ditentukan oleh seberapa besar penghasilan royalti yang diterima. Besaran royalti ditentukan oleh kesepakatan antara penulis dan penerbit, umumnya besaran pendapatan royalti sekitar $10 \%$ dari omzet penjualan buku miliknya. Selanjutnya pemerintah memungut pajak royalti menurut UU No. 36 Tahun 2008 tentang Pajak Penghasilan, PPh Pasal 23 sebesar 15\%. Pajak royalti ini merupakan pembayaran di muka (kredit pajak) yang dapat dikurangkan pada beban pajak terutang pada akhir tahun pajak.

Paling tidak ada tiga temuan penting studi yang perlu mendapat perhatian. Pertama, penulis merasa bahwa besaran pajak royalti masih terlalu besar. Penghitungan besaran pajak terutang penulis dengan mempertimbangkan skema norma penghitungan penghasilan neto (NPPN), besaran penghasilan tidak kena pajak (PTKP), dan tarif pajak progresif, 
memperlihatkan kondisi kelebihan bayar penulis, untuk pendapatan bruto sekitar Rp1 miliar. Kelebihan bayar yang dilakukan oleh penulis sebetulnya tidak menjadi masalah karena penulis dapat melakukan restitusi. Namun demikian, pengurusan proses restitusi, dirasa merepotkan. Gambar 3 menunjukkan pajak royalti yang dipungut jauh lebih besar dari pajak penghasilan yang seharusnya dibayar oleh penulis. Terlebih lagi, di Indonesia belum banyak penulis yang mendapat penghasilan yang cukup besar dari hasil karyanya, sehingga belum dapat dijadikan sumber penghasilan utama. Sebagian besar penulis bahkan mendapatkan royalti kurang dari 108 juta rupiah per tahun, sehingga seharusnya belum wajib membayar pajak.

\section{Gambar 3. Pajak Royalti (PPh 23) dan PPh yang Seharusnya Dibayar}

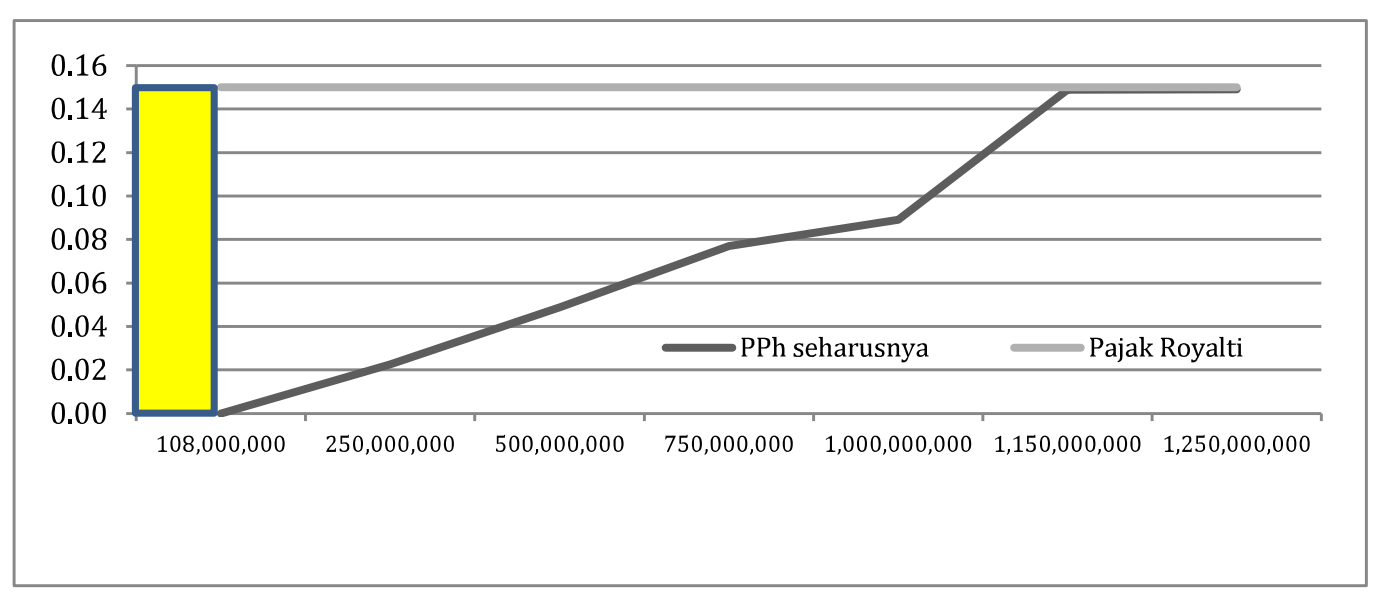

Sumber: Data primer diolah

Kedua, banyak penulis yang belum mamahami fasilitas NPPN dan cara untuk melakukan restitusi. Banyak penulis juga menilai prosedur restitusi pajak yang rumit dan ketakutan untuk diaudit. Dalam kondisi ini dapat dipastikan selalu terjadi kelebihan bayar pajak. Ketiga, banyak penulis yang menyatakan tidak mendapatkan laporan penjualan dan bukti potong pajak dari penerbit. Sering terjadi ketidaktransparanan tentang berapa tiras buku yang terjual, berapa royalti yang seharusnya diterima dan berapa pajak yang dibayarkan. Keempat, penulis menganggap pajak royalti yang tinggi merupakan bukti bahwa pemerintah tidak berpihak terhadap penulis dan terhadap upaya mencerdaskan kehidupan bangsa. Kelima, sistem perpajakan yang membedakan PPN untuk beberapa kategori buku, dianggap terlalu rumit dan perlu penyederhanaan.

Di antara pelaku sektor perbukuan, posisi penulis dapat dikatakan yang paling lemah. Gambar 4 menggambarkan perkiraan porsi perolehan hasil bruto dari setiap pelaku perbukuan. Gambar tersebut menunjukkan bahwa penulis mendapatkan porsi paling kecil yaitu sekitar $8,5 \%$, sementara penerbit mendapatkan $17,3 \%$ dan pemerintah mendapat 10,6\% dari $\mathrm{PPh}$ royalti dan PPN. Porsi terbesar diterima toko buku dan distributor (50\%). Penulis merupakan pelaku yang paling tidak diuntungkan dengan sistem tata niaga yang ada saat ini. Karenanya, saat ini banyak penulis yang memilih self-publishing atau menerbitkan karyanya melalui penerbit Indie. Dengan memilih menerbitkan secara self-publishing, penulis dapat memperoleh tingkat penghasilan yang relatif lebih besar karena tidak harus berbagi dengan pelaku lain, seperti penerbit, distributor ataupun toko buku. Namun demikian, banyak penulis mengeluhkan, bahwa mengambil jalan self-publishing membuat mereka tidak fokus bekerja sebagai penulis. Tentu saja jika semua penulis melakukan self-publishing, tidak hanya akan mengancam industri perbukuan, tetapi juga ada potensi hilangnya pendapatan pajak negara. 
Gambar 4. Porsi Perolehan Hasil Bruto dari Setiap Pelaku Perbukuan

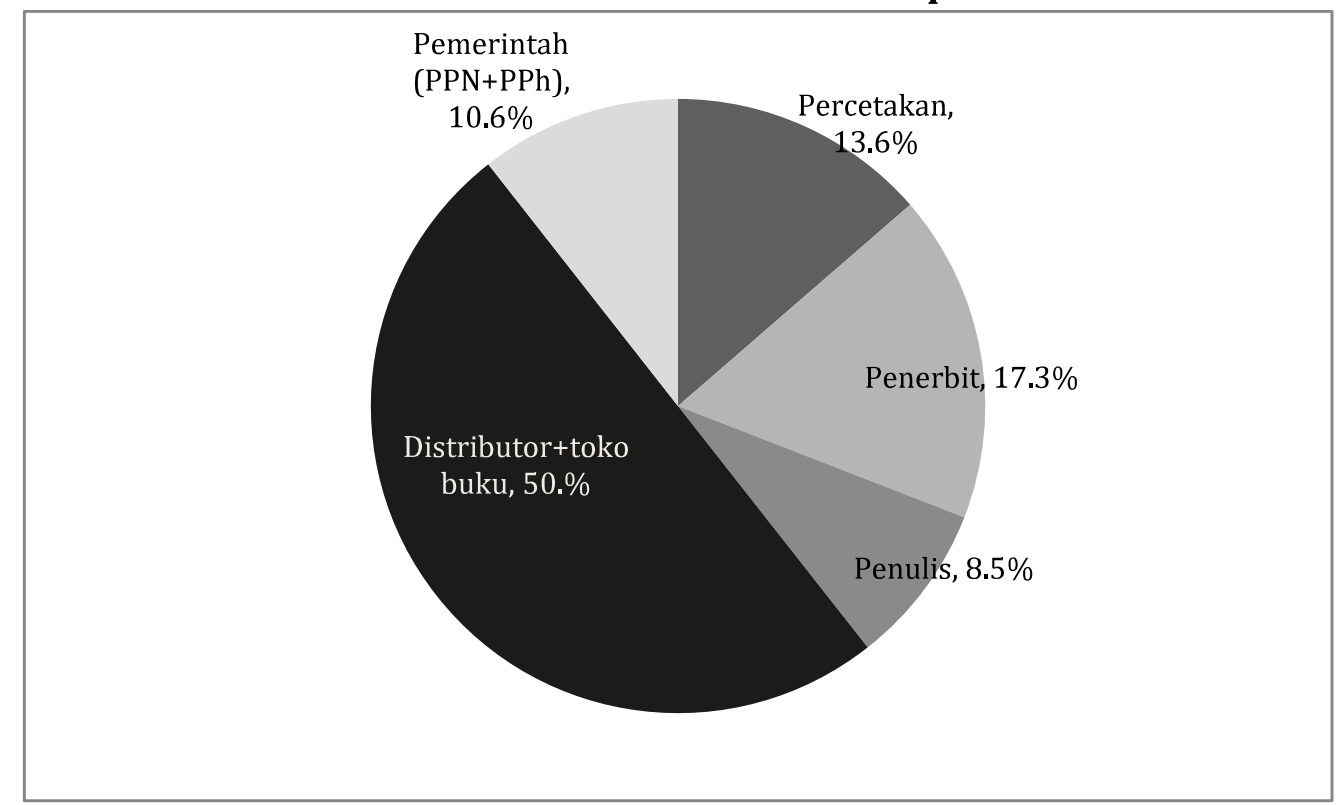

Sumber: Data primer diolah

Berkaitan dengan pajak pertambahan nilai, berdasarkan Permenkeu No. 122/PMK.011/2013, pemerintah telah memberikan pembebasan PPN untuk buku pelajaran umum, kitab suci, dan buku pelajaran agama, serta semua buku yang mendapat pengesahan dari institusi terkait (Kemendikbud dan Kemenag). Namun, hal tersebut belumlah cukup. Dalam kenyataannya, sulit untuk menentukan sebuah buku yang tidak mengandung unsur pendidikan atau pelajaran. Pengurusan rekomendasi bebas pajak juga dirasakan tidak sederhana dan penuh ketidakpastian. Baik penulis dan penerbit meminta penurunan PPN buku. Mereka juga meminta supaya PPN bahan baku, terutama untuk kertas, dihapuskan. Dengan insentif fiskal bahan baku kertas, diharapkan biaya penerbitan dapat diturunkan.

\section{DASAR PERLUNYA PEMBERIAN INSENTIF FISKAL BAGI BUKU}

Buku bukan sekadar 'Karya tulis dan/atau karya gambar yang diterbitkan berupa cetakan berjilid atau berupa publikasi elektronik yang diterbitkan secara tidak berkala', seperti definisi Pasal 1 Undang-Undang No. 3 Tahun 2017 tentang Sistem Perbukuan. Buku merupakan jendela untuk melihat dunia luas tak bertepi, yang setiap lembarnya bisa mengantarkan kita pada dunia imajinasi dan perspektif yang lain. Dengan membaca buku, pembaca akan memperoleh pengetahuan dan pemahaman yang dapat membangun kearifan. Informasi dan gagasan dalam buku membantu memperkaya perspektif, ide dan cara-cara baru dalam memecahkan persoalan.

Buku merupakan 'senjata yang kukuh dan berdaya hebat untuk melakukan serangan maupun pertahanan terhadap perubahan sosial, termasuk perubahan nilai-nilai manusia dan kemasyarakatan ${ }^{4}$. Upaya mencerdaskan kehidupan bangsa yang merupakan amanah konstitusi tidak bisa dilakukan tanpa buku. Ketersediaan buku diperlukan sebagai sarana untuk membangun dan meningkatkan literasi bangsa, sehingga mampu berperan dalam tingkat global. Lebih jauh, buku merupakan identitas, proses dan produk budaya yang penting dalam menentukan peradaban bangsa.

\footnotetext{
${ }^{4}$ Kutipan dari bahan kelompok diskusi terpumpun.
} 
Indonesia telah menunjukkan bahwa pendidikan merupakan hal penting dan prioritas yang harus dilakukan untuk mencerdaskan kehidupan bangsa. Hal ini terlihat dari program wajib sekolah 12 tahun dan politik anggaran yang mensyaratkan bahwa 20 persen dari APBN harus dialokasikan untuk pendidikan. Prioritas pembangunan bangsa tersebut tidak akan berhasil jika tidak ada buku yang tersedia secara merata bagi seluruh warga Indonesia.

Buku juga memiliki efek pengganda dan peran penting dalam menumbuhkan industri kreatif di Indonesia. Sebuah novel bukanlah hasil akhir yang akan dengan segera dilupakan, tetapi konten ceritanya perlu terus diolah dalam bentuk media lain seperti film, pertunjukan teater, musik, fashion, hingga merchandise (transmedia storytelling). 'Laskar Pelangi' karya Andrea Hirata, 'Filosofi Kopi' karya Dewi Lestari, 'Ayat-Ayat Cinta' karya Habiburrahman, 'Negeri Lima Menara' karya Ahmad Fuadi, dan 'Kambing Jantan' karya Raditya Dika, merupakan novel-novel best seller yang berhasil menyedot jutaan penonton ke gedung-gedung bioskop. Lebih jauh, mereka juga mampu menghadirkan dan memengaruhi perspektif dan gaya hidup masyarakat (Kompas, November 10, 2017), dan menggerakkan berbagai sektor ekonomi yang lain, mendorong produktivitas dan meningkatkan potensi pajak.

Pada level internasional, karya-karya klasik Shakespeare terus diproduksi menjadi pertunjukan teater dan buku-buku yang dipelajari di sekolah. Demikan juga dengan 'Harry Potter' karya J.K. Rowling yang selalu ditunggu kehadirannya, baik dalam bentuk novel maupun filmnya. Di Jepang, kita bisa melihat bagaimana karakter-karakter dalam manga atau komik, seperti Doraemon, Naruto, Detective Conan, Captain Tsubasa dan One Piece, mampu terus diproduksi dalam berbagai bentuk seperti film animasi, game, dan merchandising.

Secara ringkas, buku tidak hanya memberi nilai tambah dalam ekosistemnya. Lebih dari itu, buku akan memberi efek pengganda terhadap berbagai sektor ekonomi, sosial, dan budaya. Gagasan-gagasan kreatif yang muncul dari buku dapat menggerakkan sektor perfilman, pariwisata, merchandising, kuliner, pertanian dan sebagainya. Sayangnya, sulit untuk menghitung secara langsung multiplier effect yang ditimbulkan oleh setiap judul buku, karena tidak setiap judul mampu memberikan pengaruh yang sama. Namun, yang penting diperhatikan adalah dengan lingkungan yang kondusif, maka akan semakin banyak penulis yang muncul dengan ide-ide kreatifnya. Dengan semakin banyaknya penulis yang berkarya, kemungkinan untuk munculnya buku-buku berkualitas dan memiliki efek pengganda bagi sektor lain akan semakin besar. Terlebih lagi dalam era globalisasi, jika pemerintah gagal menjadikan penulis sebagai 'aset' bangsa, bukan tidak mungkin mereka akan 'hijrah' atau 'dibajak' oleh negara lain, yang mampu menjadikan mereka sebagai tokoh penting dalam membangun peradaban.

\section{USULAN INSENTIF PAJAK PENERBITAN BUKU}

Berdasarkan pada Undang-Undang No. 3 Tahun 2017 Tentang Sistem Perbukuan Pasal 35 butir (d) dikatakan guna mendorong industri perbukuan (Pemerintah Pusat) memberikan insentif fiskal untuk pengembangan perbukuan. Sebetulnya, pemerintah melalui Peraturan Menteri Keuangan No. 122/PMK.011/2013, tanggal 27 Agustus 2013, telah membebaskan pajak pertambahan nilai (PPN) untuk buku pelajaran umum, kitab suci, dan buku pelajaran agama. Namun demikian, masih diperlukan langkah-langkah lanjutan untuk lebih menggairahkan ekosistem kegiatan penerbitan buku, yang sejak tiga tahun terakhir ini menunjukkan kondisi yang kurang menggembirakan. Paling tidak ada tiga usulan insentif perpajakan yang dapat dilakukan oleh pemerintah, yaitu: insentif royalti penulis; insentif pajak pertambahan nilai; dan 
insentif lainnya.

\subsection{Usulan Insentif Pajak Royalti Penulis}

Ada dua cara untuk melakukan penghitungan penghasilan kena pajak yaitu: menggunakan pembukuan; dan menggunakan norma penghitungan penghasilan netto (NPPN). Pemilihan cara NPPN akan jauh lebih sederhana dibandingkan dengan menggunakan pembukuan. Namun, ada tiga kondisi yang harus dipenuhi untuk mendapatkan fasilitas tersebut yaitu: penghasilan bruto dari kegiatan usaha atau pekerjaan bebas sebagai penulis dalam 1 (satu) tahun kurang dari Rp4,8 miliar; wajib melakukan pencatatan; dan, wajib memberitahukan mengenai penggunaan NPPN kepada Dirjen Pajak paling lambat 3 (tiga) bulan sejak awal tahun pajak yang bersangkutan.

Dalam Peraturan Dirjen Pajak No. Per-17/PJ/2015, disebutkan kegiatan pekerja seni masuk dalam klasifikasi lapangan usaha (KLU) kode 90002. Dalam peraturan tersebut, dikatakan, kelompok ini mencakup kegiatan pekerjaan seni seperti novelis, penulis cerita dan pengarang lainnya, aktor, penyanyi, penari sandiwara, penari dan seniman panggung lainnya yang sejenis. Termasuk pula usaha kegiatan produser radio, televisi, dan film, penulis, kartunis, dan pemahat. Dengan menggunakan NPPN, penulis berhak mendapatkan pemotongan pajak sebesar lima puluh persen (50\%), atas penghasilan bruto yang diterima.

Sebetulnya tidak banyak penulis yang mampu memperoleh pendapatan bruto maksimal Rp4,8 miliar dalam setahun atau dalam sebulan rata-rata sekitar Rp400 juta. Dari hasil diskusi dengan beberapa penulis, yang bukunya tergolong sebagai best seller di salah satu toko buku ternama, baru mendapatkan royalti sekitar Rp120 juta per tahun. Tentu saja saja masih banyak penulis yang pendapatannya jauh di bawah itu. Oleh karenanya, ada dua pilihan yang dapat diambil, yaitu: revisi pajak royalti atau pengenaan PPh final.

Pilihan melakukan revisi pajak royalti didasari oleh temuan studi ini yang menunjukkan adanya 'kinked royalti tax curve' dalam hal pembayaran pajak royalti. Fenomena ini terjadi karena dalam rentang pendapatan bruto penulis hingga kurang lebih sekitar Rp1 miliar (asumsi pendapatan penulis hanya dari menulis), selalu terjadi kelebihan bayar. Artinya, pajak royalti sebesar $15 \%$ akan mendekati kondisi riil, jika diterapkan kepada penulis dengan pendapatan lebih dari Rp1,2 miliar. Merujuk pada ketentuan penghasilan tidak kena pajak (PTKP) Rp54 juta/tahun, maka untuk penghasilan bruto penulis Rp108 juta, seharusnya pajak royalti yang dikenakan sebesar nol persen (0\%).

Untuk rentang pendapatan bruto penulis antara Rp108 juta - Rp1 miliar, terjadi kenaikan progresif 'royalti tax ratio', namun demikian tidak banyak penulis yang berada pada zona pendapatan demikian. Sehingga, guna mencapai efektivitas dan kemudahan pengadministrasian pajak royalti, maka bagi penulis dengan penghasilan bruto kurang dari Rp1 miliar, sangat pantas untuk dibebaskan dari pajak royalti.

Data yang ditampilkan oleh Direktorat Potensi, Pepatuhan dan Penerimaan, Direktorat Jenderal Pajak, Kementerian Keuangan, untuk Klasifikasi Lapangan Usaha (KLU) 58110 Penerbitan Buku, di tahun 2016, total PPh Pasal 23 Royalti yang diterima pemerintah sekitar Rp14,7 miliar, dan hingga Agustus 2017 sekitar Rp17,3 miliar. Besar nilai penerimaan negara atas royalti, sebetulnya sangat kecil sekali dibandingkan dengan target penerimaan pajak di tahun 2017 sebesar Rp1.283,6 triliun. Dengan demikian, kebijakan untuk melakukan pelonggaran atas pajak royalti penulis, tidak akan berdampak terhadap target penerimaan 
negara.

Namun demikian untuk melakukan usulan perbaikan pajak royalti, diperlukan perubahan undang-undang $\mathrm{PPh}$. Hal ini tentu saja memerlukan waktu dan proses yang panjang. Solusi alternatif yang lebih praktis yaitu dengan melakukan 'adaptasi' atas istilah royalti yang akan mengunci pada pajak royalti sebesar 15\%. Sebagaimana disebutkan dalam UU Sistem Perbukuan, penerimaan penulis tidak hanya royalti, namun juga honorarium dan upah.

Pilihan kedua yakni pengenaan PPh final, dapat dipertimbangkan oleh penulis. Dalam Peraturan Pemerintah Nomor 46 Tahun 2013, terkait dengan PPh final, diberikan kepada wajib pajak yang menerima penghasilan dari usaha, tidak termasuk penghasilan dari jasa sehubungan dengan pekerjaan bebas, dengan peredaran bruto tidak lebih dari Rp4,8 miliar dalam 1 tahun pajak. Dalam ketentuan tersebut disebutkan, pengarang, peneliti, dan penerjemah masuk dalam pekerjaan yang dapat mendapatkan PPh final sebesar 1\% dari pendapatan bruto. Akan tetapi, penulis perlu melakukan penghitungan secara cermat, akan prospek pendapatan bruto yang akan ia terima, serta memilih mana yang lebih menguntungkan antara penggunaan PPh final atau NPPN. Misalkan untuk pendapatan bruto di atas Rp200 juta, maka penggunaan PPh final akan jauh lebih menguntungkan. Dengan lain perkataan untuk pendapatan di bawah Rp200 juta penggunaan NPPN akan lebih menguntungkan dan penulis dapat memberikan nama royalti atas pendapatan yang diterima. Namun, tentu saja, karena penggunaan NPPN mengarah pada ajuan restitusi, ada biaya transaksi yang perlu diperhitungkan seperti waktu, dan biaya lainnya.

Pilihan ketiga adalah menaikkan batas restitusi pajak ditarik di muka. Sebagaimana disebutkan dalam Peraturan Menteri Keuangan, PMK No. 198/PMK.03/2013 tentang Pengembalian Pendahuluan Kelebihan Pembayaran Pajak Bagi Wajib Pajak Yang Memenuhi Persyaratan Tertentu, disebutkan jumlah maksimum lebih bayar restitusi pribadi adalah Rp10.000.000. Dengan mempertimbangkan bahwa, selalu terjadi kelebihan bayaran untuk penghasilan bruto penulis di bawah Rp1 miliar. Dengan skenario pendapatan bruto sebesar tersebut, maka besaran restitusi sekitar Rp73,5 juta. Dengan, demikian, dalam peraturan tersebut dapat dikecualikan untuk penulis dengan penghasilan royalti mencapai Rp1 miliar, maka restitusi yang dapat ditarik dimuka maksimum sebesar Rp73,5 juta. Tentu saja, opsi ini akan memberikan konsekuensi akan kepatuhan pajak yang tinggi dari wajib pajak.

\subsection{Usulan Insentif Pajak PPN}

Buku, dalam jenis bentuk apapun, merupakan komoditas strategis yang layak untuk mendapat perhatian utama dari pemerintah. Langkah positif pemerintah untuk membebaskan PPN atas buku pelajaran umum, kitab suci, dan buku pelajaran agama, dinilai sudah kurang relevan dengan dinamika perbukaan yang ada saat ini, paling tidak untuk dua alasan. Pertama, implementasi kebijakan tersebut tidaklah mudah. Surat Keterangan Bebas (SKB) Pajak Pertambahan Nilai yang diterbitkan oleh Direktur Jenderal Pajak, memerlukan pengesahan dari menteri yang menyelenggarakan urusan pemerintahan di bidang pendidikan atau pejabat lain yang ditunjuk oleh menteri. Dalam hal ini SKB tersebut menjadi otoritas Pusat Kurikulum dan Perbukuan (Puskurbuk) dan Kementerian Agama.

Kenyataan yang ada, mayoritas pelaku perbukuan, berpendapat, semua buku harus dibebaskan dari PPN karena beberapa alasan seperti: (i) buku merupakan barang strategis; (ii) jika PPN hanya diberikan untuk beberapa jenis buku saja, dalam implementasi telah menimbulkan banyak permasalahan teknis; (iii) tingkat literasi masyarakat masih sangat rendah; (iv) dapat menurunkan harga buku. 
Merujuk pada undang-undang yang mengatur pengenaan Pajak Pertambahan Nilai (PPN) dan Pajak Penjualan atas Barang Mewah (PPnBM) yaitu UU No. 8 Tahun 1983 yang selanjutnya diubah dengan UU No. 42 Tahun 2009. Selama ini barang-barang yang tidak dikenakan PPN terdiri atas kelompok: (i) barang-barang pertambangan atau hasil pengeboran yang diambil langsung dari sumbernya; (ii) barang-barang kebutuhan pokok yang sangat dibutuhkan oleh rakyat banyak; dan (iii) makanan dan minuman yang disajikan di hotel, restoran, rumah makan, warung dan sejenisnya; dan (iv) uang, emas batangan, dan surat-surat berharga (saham, obligasi, dan lainnya). Jenis barang yang tidak dikenakan PPN ditetapkan dengan Peraturan Pemerintah. Dengan demikian, buku, bisa masuk dalam kriteria (ii).

Opsi terbaik untuk insentif PPN buku yaitu fasilitas PPN tidak dipungut yang pada hakikatnya sama dengan pengenaan PPN dengan tarif 0\%. Fasilitas PPN tidak dipungut paling tepat jika diberikan pada kegiatan ekonomi yang dianggap sebagai prioritas nasional. Kebijakan PPN tidak dipungut juga diperkirakan tidak akan memberikan dampak yang berarti terhadap penerimaan negara. Di tahun 2016, PPN dalam negeri untuk klasifikasi penerbitan buku (KLU 58110) mencapai sekitar Rp7,9 miliar dan PPN hingga Agustus 2017, mencapai sekitar Rp6,9 miliar. Dengan jumlah penerimaan PPN penerbitan buku yang relatif kecil ini, maka kebijakan tidak akan terlalu mengganggu target penerimaan pajak. Bahkan, sebaliknya, kebijakan ini dapat menjadi investasi untuk memacu pertumbuhan yang lebih dinamis usaha penerbitan di masa depan.

Tujuan penting dari penerapan PPN tidak dipungut lebih pada penyederhanaan prosedur administrasi dibandingkan dengan pengaruh penurunan harga buku. Penurunan harga buku akan tergantung pada seberapa disiplin para pelaku untuk juga menyesuaikan harga buku. Penegakkan sanksi perlu dilakukan untuk meningkatkan disiplin para pelaku perbukuan. Hal ini karena, pertama, harga buku tidak semata-mata ditentukan oleh harga pokok penjualan (HPP), dalam banyak kasus harga buku juga ditentukan oleh kepandaian penerbit ataupun toko buku untuk memberikan harga psikologis. Kedua, dalam banyak kasus, untuk buku-buku yang baik menurut pandangan konsumen dan sangat diperlukan, harga tidak terlalu menjadi pertimbangan utama. Ketiga, secara teori efektivitas kebijakan harga (termasuk pajak di dalamnya) sangat dipengaruhi oleh kondisi elastisitas permintaan. Jika harga buku bisa turun karena berkurangnya besaran PPN, maka dapat dipastikan, angka penjualan atas buku-buku yang umum akan meningkat.

\subsection{Insentif Lainnya}

Bentuk-bentuk insentif lain di luar PPh dan PPN juga perlu dijajaki. Upaya secara langsung yang dapat dilakukan oleh pemerintah untuk meningkatkan minat membeli buku yaitu dengan memberikan langsung insentif kepada konsumen akhir. Pemerintah dapat memberikan potongan langsung/discount/voucher buku di banyak toko buku yang ada di Indonesia. Pemerintah dapat mengintegrasikan program ini bersamaan dengan program pendidikan wajib 12 tahun melalui program Kartu Indonesia Pintar.

Insentif lain melalui pembebasan Pajak Bumi dan Bangunan (PBB). Toko buku dan taman baca milik komunitas atau pribadi yang terbuka untuk umum perlu dibebaskan dari PBB, dengan pertimbangan: lokasi tersebut merupakan sumber mencari ilmu; dan lebih banyak menjalankan fungsi sosial. Agar kebijakan ini berjalan baik, maka diperlukan dukungan pemerintah daerah untuk turut berinovasi guna mendukung ekosistem penerbitan dan literasi masyarakat. 
Upaya lain adalah mendorong peran perpustakaan. Dunia pendidikan merupakan basis penting atas permintaan buku nasional. Namun demikian, saat ini anggaran pembelian buku hanya mendapatkan porsi kecil dari total belanja material ilmu di perpustakaan. Hal ini terjadi karena sebagian besar anggaran perpustakaan dipergunakan untuk berlangganan jurnal online, sehingga belanja buku harus dikorbankan. Perlu ada langkah afirmatif dari pemerintah untuk menjaga belanja buku tidak kurang bahkan terus meningkat. Walaupun belanja jurnal dan majalah adalah penting, namun hendaknya hal ini tidak harus dilakukan dengan mengorbankan pembelian buku.

Sejalan untuk meningkatkan jumlah terbitan buku Indonesia yang jumlahnya masih kurang, dunia pendidikan tinggi juga perlu memberikan apresiasi yang kurang lebih sama dalam hal angka kredit dan insentif honorarium, bagi guru, dosen, dan peneliti yang dapat menghasilkan karya tulis buku. Kecenderungan yang ada saat ini, guru, akademisi dan peneliti, lebih banyak menulis jurnal dibandingkan dengan buku. Dalam jangka panjang, hal ini dapat mengancam jumlah penerbitan buku di Indonesia.

Tidak kalah pentingnya adalah memberikan penghargaan bagi penulis buku (non akademisi dan peneliti). Dalam upaya mengakui eksistensi penulis, sangat baik jika pemerintah memberikan apresiasi kepada penulis-penulis yang mampu berikan dampak luar biasa bagi perkembangan dunia literasi di Indonesia. Pengakuan akan profesi penulis, akan semakin memotivasi penulis-penulis muda untuk menjadi penulis terkenal di masa depan.

\section{KESIMPULAN}

Gambaran kondisi makro perbukuan di Indonesia, memperlihatkan kondisi ketimpangan dalam sebaran geografis penerbit. Jawa masih menjadi kiblat atau pusat industri perbukuan nasional. Produksi buku per kapita di Indonesia masih relatif rendah dibandingkan dengan negara berkembang lainnya. Hal ini tentu tidak terlepas dari kondisi rendahnya minat membaca buku dan kemampuan untuk melakukan pemaknaan atas bacaan buku. Hal ini sekaligus mencerminkan budaya literasi Indonesia masih relatif lemah. Dalam kondisi demikian, harga buku di Indonesia memperlihatkan kecenderungan yang meningkat dan hal ini juga dibebani dengan besaran PPN yang juga relatif tinggi. Selanjutnya, kebijakan royalti bagi penulis juga kurang 'bersahabat'.

Pekerjaan penerbitan adalah suatu kegiatan kolektif dan terjadi saling ketergantungan (interdependency) antarsemua pelaku. Namun demikian, interaksi diantara para pelaku belum terbangun sinergi, bahkan ada kesan perilaku 'predator' terjadi diantara mereka. Royalti, yang diterima oleh penulis atas karya yang dihasilkan belum dapat dijadikan sumber pendapatan utama. Namun, dorongan idealisme penulis yang kuat menjadi mata air bagi banyak penulis di Indonesia untuk tetap bekarya di tengah minimnya apresiasi.

Pada sisi lain, penerbit mengeluhkan akan lesunya penjualan buku cetak. Turunnya jumlah buku yang dicetak berdampak pada kenaikan harga buku. Sementara itu, toko buku perlu membangun strategi jitu untuk melakukan diversifikasi produk yang dijual, untuk menjamin kelangsungan hidupnya. Sementara itu, perpustakaan sebagai agen penting yang dapat menumbuhkan permintaan buku, juga tidak dapat berbuat banyak karena pengurangan besarbesaran anggaran untuk membeli buku. 
Sementara itu, tidak ada kelembagaan dan organisasi perbukuan yang bertanggung jawab untuk membina dan mengembangkan dunia perbukuan. Bahkan dunia perbukuan dianggap sebagai 'anak yatim'. Pemerintah daerah pun, nampaknya belum melihat buku sebagai komoditas strategis yang harus dibangun guna meningkatkan kinerja literasi di daerahnya.

Pajak royalti yang dibayar dimuka oleh penulis, sebetulnya bukan merupakan pajak riil yang harus ditanggung oleh penulis. Dengan besaran pajak royalti sebesar 15\%, maka bagi penulis dengan pendapatan bruto sampai dengan Rp4,8 miliar, dan menggunakan norma, akan selalu terjadi kelebihan bayar. Hasil studi memperlihatkan, penulis akan menerima tiga jenis kerugian. Pertama, tertundanya potensi pendapatan yang bisa digunakan untuk mendukung kegiatan penulisan. Kedua, kelebihan bayar selalu terjadi pada penulis, terutama yang memiliki pendapatan bruto kurang dari Rp1,1 miliar. Idealnya, kelompok penulis demikian, mendapatkan insentif dan bukan disinsentif. Ketiga, penulis juga berada dalam posisi yang paling tidak diuntungkan dalam porsi perolehan hasil bruto peredaran buku. Dengan demikian, kebijakan perpajakan yang ada saat ini sangat tidak menguntungkan sebagaian besar penulis di Indonesia. Terakhir, kebijakan diskriminatif atas PPN, secara administrasi juga tidak sesuai dengan prinsip kesederhanaan.

Pemerintah perlu melakukan 're-thinking' dengan hanya memberikan perlakuan khusus terhadap buku pelajaran, buku agama, dan kitab suci. Jika buku-buku yang tidak masuk dalam kategori tersebut, ternyata mampu memberikan manfaat besar bagi upaya pencerdasan kehidupan bangsa dan menciptakan peluang-peluang dalam pengembangan ekonomi, sosial, dan budaya, maka sudah selayaknya buku dilihat sebagai suatu gagasan tidak bertepi. Akan terlalu sempit jika, tujuan mencerdaskan kehidupan bangsa dibatasi pada buku-buku tertentu. Karena buku adalah gagasan, maka penting untuk memperlakukan 'siempunya' gagasan dengan sebaiknya-baiknya dengan memberikan perhargaan kepada para penulis yang mampu berkontribusi bagi perkembangan peradaban bangsa.

Tidak ada formulasi kebijakan insentif pajak yang akan memberikan keuntungan yang sama untuk semua pelaku perbukuan. Demikian juga, tidak ada insentif pajak yang dapat memuaskan semua pihak. Namun demikian, menjadi tugas pemerintah/negara untuk memberikan banyak pilihan bagi para pelaku perbukuan, agar mereka dapat memilih menu yang paling pas dengan kondisi mereka. Setiap pilihan menu insentif, akan memberikan konsekuensi baik bagi pelaku perbukuan dan juga pemerintah. Namun demikian, semangat yang perlu dikedepankan dalam hal perpajakan yaitu syarat keadilan. Posisi umumnya penulis, selalu terjadi kelebihan bayar pajak royalti, dan juga dalam posisi 'terpinggirkan' dalam mata rantai perbukuan. Dengan kondisi ini, maka keberpihakan kepada penulis menjadi suatu keharusan.

\section{UCAPAN TERIMA KASIH}

Tulisan ini merupakan bagian dari kerjasama penelitian antara Direktorat Harmonisasi Regulasi dan Standardisasi Deputi Fasilitasi HKI dan Regulasi Badan Ekonomi Kreatif dan Pusat Penelitian Ekonomi - LIPI. Pendanaan Studi ini sepenuhnya didukung oleh Badan Ekonomi Kreatif. 


\section{DAFTAR PUSTAKA}

BEKRAF \& BPS. (2017). Data statistik dan hasil survei ekonomi kreatif. Jakarta: Hasil Survei Khusus Ekonomi Kreatif. Retrieved from http://www.bekraf.go.id/downloadable/pdf_file/170475-data-statistik-dan-hasilsurvei-ekonomi-kreatif.pdf

IKAPI. (2015). Industri penerbitan buku Indonesia: Dalam data dan fakta. Jakarta: Ikatan Penerbit Indonesia. Retrieved from https://www.academia.edu/19579907/Industri_Penerbitan_Buku_Indonesia_dalam_Dat a_dan_Fakta

IPA. (2016a). IPA annual report: 2015 - 2016. Geneva: International Publishers Association. Retrieved from https://www.internationalpublishers.org/images/reports/Annual_Report_2016/IPA_An nual_Report_2015-2016_interactive.pdf

IPA. (2016b). VAT on books: The IPA-FEP annual global report. Retrieved from https://www.internationalpublishers.org/images/reports/Annual_Report_2016/IPA_FE P_VAT_report_2016.pdf

Kompas. (2017, September 11). "Tentang Tere Liye", curhat Sri Mulyani soal pajak penulis. (A. Ika, Editor) Retrieved from https://ekonomi.kompas.com/read/2017/09/11/155413026/tentang-tere-liye-curhatsri-mulyani-soal-pajak-penulis?page=all

Kompas. (2017, November 10). Budaya nongkrong di kedai kopi yang tak pernah pudar. (L. K. Anna, Editor) Retrieved from Kompas.com: https://lifestyle.kompas.com/read/2017/11/10/081400420/budaya-nongkrong-dikedai-kopi-yang-tak-pernah-pudar

Kompas. (2017, September 8). Protes Tere Liye dan jalan sunyi dunia literasi. (P. A. Auliani, Editor) Retrieved from Kompas.com: https://edukasi.kompas.com/read/2017/09/08/22200901/protes-tere-liye-dan-jalansunyi-dunia-literasi?page=all

Kompas. (2019, September 8). Apa sebenarnya akar masalah pajak penulis yang dikeluhkan Tere Liye? (A. Ika, Editor) Retrieved from Kompas.com: https://ekonomi.kompas.com/read/2017/09/08/053128326/apa-sebenarnya-akarmasalah-pajak-penulis-yang-dikeluhkan-tere-liye?page=all

Kontan. (2017, September 8). Dee Lestari bicara soal pajak penulis. (Y. Winarto, Editor) Retrieved from Kontan.co.id: https://nasional.kontan.co.id/news/dee-lestari-bicarasoal-pajak-penulis?page=all

MABOPA. (2016). Country report: Malaysia 2016. Retrieved from http://mabopa.com.my/upload/attc/ABPA-Malaysia Country Report 2016 May 7th.pdf

Mardiasmo. (2009). Perpajakan. Yogyakarta: Penerbit Andi.

Nicholson, W., \& Snyder, C. (2009). Intermediate microeconomics and its application. Ohio, USA: South-Western Cengage Learning. 
PwC. (2017, November 17). Dividend, interest, and royalty WHT rates for WWTS countries. Retrieved from http://taxsummaries.pwc.com/ID/Withholding-tax-(WHT)-rates

Stiglitz, J. (1998). Distinguished lecture on economics in government; The private uses of public interest: Incentives and institutions. Journal of Economic Perspectives, 12(2), 3-22. Retrieved from https://pubs.aeaweb.org/doi/pdfplus/10.1257/jep.12.2.3

TIMSS \& PIRLS International Study Center. (2011). PIRLS 2011 international results in reading. Retrieved from https://timssandpirls.bc.edu/pirls2011/downloads/P11_IR_FullBook.pdf 
180 | Bina Ekonomi

Halaman ini sengaja dikosongkan 